\title{
30th Anniversary Issue
}

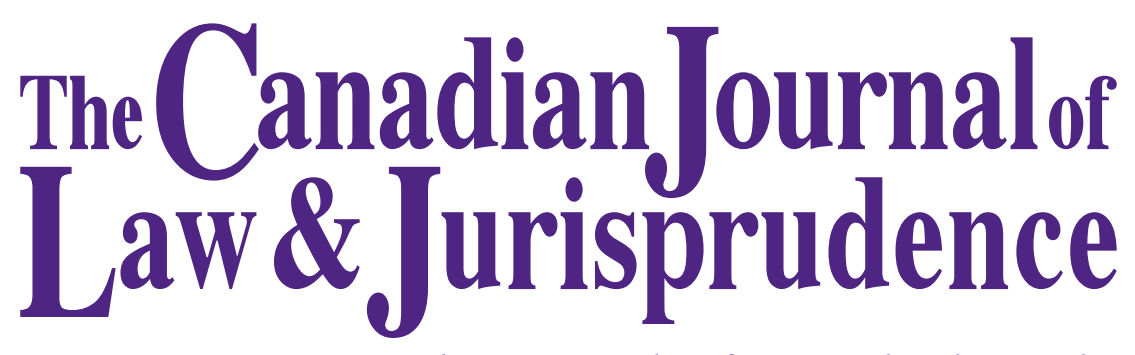

An International Journal of Legal Thought

Vol. XXX No.2 August 2017

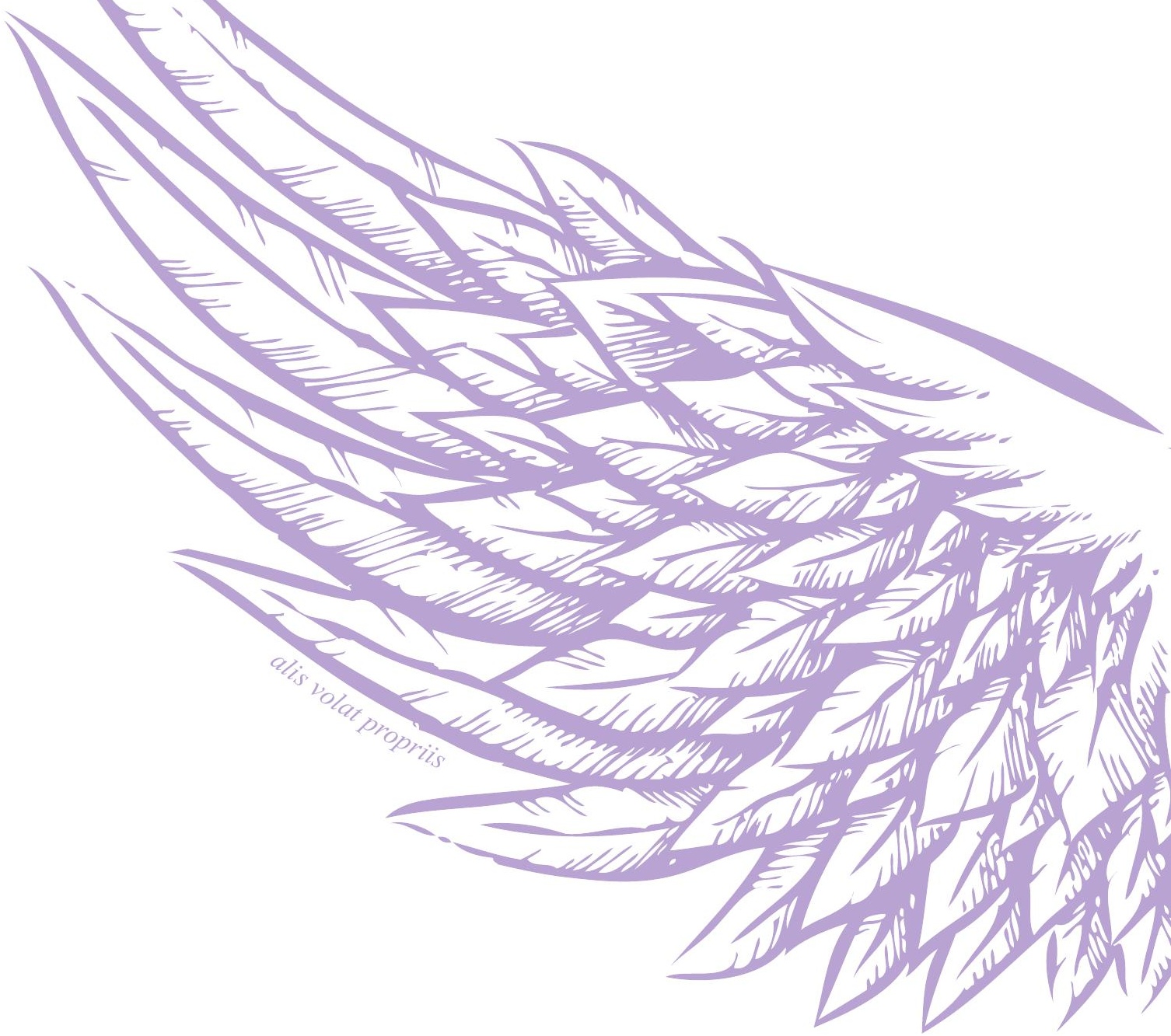




\section{Statement of Purpose}

The Canadian Journal of Law \& Jurisprudence serves as a forum for the publication of scholarly writing in general and special jurisprudence and legal philosophy. In this regard it will publish articles that address the nature of law, the philosophical analysis or criticism of substantive and procedural doctrine, that explore the philosophical bases of constitutional law, that examine the form and nature of legal or judicial reasoning, that investigate issues concerning the ethical aspects of legal practice, and that study (from a philosophical perspective) concrete issues facing contemporary society.

\section{Editorial Board}

\section{Editors}

Richard Bronaugh

Andrew Botterell

Production Editor

Regina Satorius

Student Editors

Oliver Hutchinson

Christina Iannozzi

David Isaac

Alyssa Jervis

James Judson

Emily Owens

Cristina Tomaino

Claudia Warner-Romano

Western Law Coordinator

Tigger Jourard

\author{
Consulting Editors \\ Alan Brudner \\ Bruce Chapman \\ David Dyzenhaus \\ Leslie Green \\ Barry Hoffmaster \\ Charles Jones \\ Dennis Klimchuk \\ Margaret Martin \\ Michael Milde \\ Dennis M. Patterson \\ Denise Réaume \\ Arthur Ripstein \\ Wayne Sumner \\ Mark Thornton \\ Richard Vernon \\ Wil Waluchow \\ Grégoire C. N. Webber \\ Ernest Weinrib
}

Cover: The motto of this Journal is alis volat propriis. What this motto says is that we fly on our own wings. What it has meant was our being not only self-sustaining and self-publishing, but also going wide with regard to what we view as jurisprudentially attractive and worthwhile as philosophical discovery. The people at Cambridge University Press observed that $C J L J$ has been a successful journal in the field of legal philosophy and they wanted in on the flight. Our prospects have opened and our wings will spread.

Beginning with Volume 28 the Canadian Journal of Law \& Jurisprudence has been published jointly by Cambridge University Press and the Faculty of Law, the University of Western Ontario.

Appreciation is expressed to SSHRC for the aid to scholarly journals we receive.

The journal is included in the Cambridge Core service and can be found at cambridge.org/cjlj.

ISSN: 0841-8209

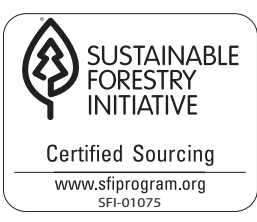

Applies to text only 


\section{The Canadian Journal of Law \& Jurisprudence}

Vol. XXX No.2 August 2017

\section{TABLE OF CONTENTS}

Annalise Acorn

Thomas Bustamante

Daniel

Davison-Vecchione and Kate Pambos

Daniel Del Gobbo

Colin Grey

David A. Reidy

Péter Sólyom

Shai Stern

W. Bradley Wendel

Aleardo Zanghellini
Should the Injustice Done to Her be

the Law's Concern? The Case of Cinderella

Revisiting Dworkin's Philosophy of International Law: Could the Hedgehog

Have Done It Any Other Way?

Steven M. Wise and the

Common Law Case for Animal Rights:

Full Steam Ahead

Unreliable Narration in Law and Fiction 311

Refugee Law and Its Corruptions

Moral Psychology, Stability and The

Law of Peoples

Between Legal Technique and Legal Policy:

Remarks on Hans Kelsen's

Constitutional Theory

Remodeling Just Compensation:

Applying Restorative Justice to Takings

Law Doctrine

The Limits of Positivist Legal Ethics:

A Brief History, a Critique, and a Return

to Foundations

A Conceptual Analysis of Conceptual Analysis

in Analytic Jurisprudence

alis volat propriis

\section{Western\&Law}




\section{AUTHORS}

Annalise Acorn (B.A., LL.B., LL.M., University of Alberta; B.C.L., Oxford, 1988) is Professor of Law at the University of Alberta. She is the author of Compulsory Compassion: a critique of restorative justice (2004). Her research interests include legal theory, philosophy of the emotions and justice and law and literature. Email: aacorn@ualberta.ca

Thomas Bustamante (LL.B., Juiz de Fora; M.Phil., State University Rio de Janeiro; Ph.D., Pontifical Catholic University of Rio de Janeiro, 2007) is Professor of Legal Theory at the Federal University of Minas Gerais, Brazil, and Recipient of Productivity Research Scholarship from Brazil's National Council for Scientific and Technological Development (CNPq). His research includes works on legal theory, political philosophy and constitutional law.

Email: tbustamante@ufmg.br

Daniel Davison-Vecchione (LL.B., University of Surrey; LL.M. in Legal Theory, New York University, 2015) is an Associate Lecturer in Law at the University of Surrey in Guildford, Surrey. His current research focuses on social theory and the philosophy of law. Email: d.davisonvecchione@gmail.com

Daniel Del Gobbo (B.A. Hons., Queen's; J.D., Osgoode Hall; LL.M., Harvard, 2015) is an Adjunct Professor at Osgoode Hall Law School and S.J.D. Candidate at the University of Toronto Faculty of Law. His research interests include dispute resolution, civil procedure, and critical legal theory.

Email: daniel.delgobbo@mail.utoronto.ca

Colin Grey (B.A., Dartmouth College; LL.B., University of Toronto; LL.M., J.S.D., New York University, 2011) is professor of law at the Universite du Québec à Montréal and the author of Justice and Authority in Immigration Law (2015). For four years, he acted as legal advisor at the Immigration and Refugee Board of Canada. Email: grey.colin@uqam.ca

Kate Pambos (LL.B., University of Surrey; L.P.C. \& LL.M., University of Law, 2016) is a law graduate whose research interests include animal rights.

Email: katepambos@gmail.com

David A. Reidy (B.A., DePauw University; J.D., Indiana University; Ph.D., University of Kansas, 1997) is Professor of Philosophy and Distinguished Humanities Professor at the University of Tennessee. He has authored On the Philosophy of Law (2006) and edited or co-edited volumes, including The Blackwell Companion to Rawls (2014), The Cambridge Rawls Lexicon (2015), Human Rights: The Hard Questions (2013), and Rawls's Law of Peoples: A Realistic Utopia? (2006). He is currently working on a monograph, drawing on archival research, that presents the development of Rawls's work from 1940 to his death. Email: dreidy@utk.edu 
Péter Sólyom (M.A., Eötvös Lóránd University Budapest, Hungary; Ph.D., University of Miskolc, Hungary, 2013) is Associate Professor of the Department of Constitutional Law at the University of Debrecen, Hungary. His research includes works on legal theory, political philosophy and constitutional law.

Email: solyom.peter@law.unideb.hu

Shai Stern (LL.B., Bar Ilan University; LL.M., Tel Aviv University; D.Phil., Tel Aviv University, 2014) is an assistant professor at Bar Ilan University, Israel. His research centers on private law theory, property law, expropriation law and the law of communities. Email: shai.stern@biu.ac.il

W. Bradley Wendel (B.A., Rice University; J.D., Duke University; LL.M., J.S.D., Columbia University) is Professor of Law at Cornell University. He is the author of Lawyers and Fidelity to Law (2010) and Ethics and Law: An Introduction (2014). His research focuses on the intersection of professional ethics and legal and political philosophy. Email: wbw9@cornell.edu

Aleardo Zanghellini (J.D., Milan; LL.M., UBC; M.St., Oxford; Ph.D., Sydney, 2005) is Professor of Law \& Social Theory at the University of Reading. He has broad interests in legal, political and moral philosophy, as well as in the field of law, gender and sexuality. Email: a.zanghellini@reading.ac.uk 